\title{
Development and Validation of a Simple, Rapid and Stability-Indicating High Performance Liquid Chromatography Method for Quantification of Norfloxacin in a Pharmaceutical Product
}

\section{Lucas Chierentin and Hérida Regina Nunes Salgado*}

School of Pharmacy, Faculty of Pharmaceutical Sciences, São Paulo State University, Araraquara, São Paulo, Brazil

\begin{abstract}
A stability-indication high performance liquid chromatographic method has been developed for the determination of norfloxacin in tablet dosage forms. Optimum separation was achieved in less than 7 minutes using Eclipse Plus Zorbax C18 Agilent, $150 \mathrm{~mm} \times 4.6 \mathrm{~mm}$ i.d., $5 \mu \mathrm{m}$ particle size column. The analyte was resolved by using a mobile phase $5 \%$ acetic acid aqueous solution and methanol $(80: 20, \mathrm{v} / \mathrm{v})$ at a flow rate $1.0 \mathrm{ml} / \mathrm{min}$ on an isocratic high performance liquid chromatographic system at a wavelength of $277 \mathrm{~nm}$. Linearity, system suitability, precision, sensitivity, selectivity, specific, and robustness were established by International Conference Harmonization guidelines. For stress studies the drug was subjected to photolysis, oxidation, acid, alkaline and neutral conditions. The analytical conditions and the solvent developed provided good resolution within a short analysis time and economic advantages. The proposed method not required sophisticated and expensive instrumentation.
\end{abstract}

Keywords: Degradation products; HPLC-UV; Liquid chromatography; Norfloxacin; Stability-indicating method; Validation

\section{Introduction}

Norfloxacin is the first synthetic second-generation fluoroquinolone antimicrobial drug. It was developed for use in human and veterinary medicine [1]. Norfloxacin, occasionally used to treat common, as well complicated urinary tract infections, exhibits a broad spectrum of activity against Gram-positive and Gram-negative bacteria [2-4]. Chemically, it is 1-ethyl-6-fluoro-1,4-dihydro-4-oxo-7-(1-piperazinyl)3 -quinoline carboxylic acid (Figure 1). The mechanism of the bacterial effect of norfloxacin is based on the primary target in bacterial enzyme DNA gyrase and topoisomerase II and IV. Inhibition of the activity of these enzymes disables DNA replication which in turn, inhibits bacterial replication $[5,6]$.

In addition, good tolerability and a favorable safety profile make the fluoroquinolones important therapeutic options for the treatment of infections caused by antibiotic-resistant bacteria [7].

Several analytical methods for norfloxacin have been described in scientific literature, such as titrimetry UV spectrophotometry, and liquid chromatography, amongst others [8-14]. The high performance liquid chromatography (HPLC) has become an important tool for the routine determination of antimicrobial drugs, with specific emphasis on fluoroquinolones, in edible animal products, environmental, feed, biological fluids and pharmaceutics products, with specific emphasis on fluoroquinolones [15-19].

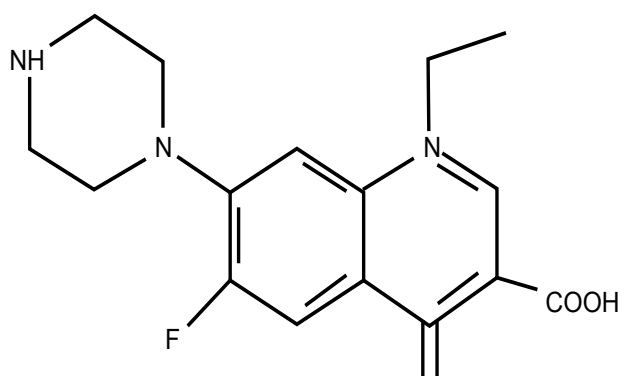

Figure 1: Chemical Structure of Norfloxacin (CAS: 70458-96-7).
In the literature, there are some references about the determination of norfloxacin using HPLC methodology. Espinosa-Mansilla and coworkers reported this methodology with photoinduced fluorimetric (PIF) detection, used to determine four fluoroquinolones in serum and plasma samples [20]. In another work, Patel et al. improve one method for estimation of norfloxacin and ornidazole in their combined dosage form [21]. Most of the reported methods involve troublesome mobile phase (buffers) and sample preparation.

A thorough literature search has revealed that one method was reported for separation and determination of the process related synthetic impurities of norfloxacin and one other studied of photostability of norfloxacin contained in directly compressible tablets and estimated the closely related ethylenediamine degrade by HPLC $[17,22]$.

Our investigation involved the optimization of the method described above using a reliable stability indicating and one new development, as well as validating a simple, sensitive, accurate and reproducible HPLC method for the determination of norfloxacin in pharmaceutical dosage forms.

\section{Experimental}

\section{Reagents and chemicals}

Methanol and acetic acid were HPLC grade (Merck, Germany) Sodium hydroxide $(\mathrm{NaOH})$, hydrogen peroxide $\left(\mathrm{H}_{2} \mathrm{O}_{2}\right)$ and hydrochloric acid $(\mathrm{HCl})$ were obtained from Synth (São Paulo, Brazil). Norfloxacin standard (purity 100\%) and pharmaceutical product

*Corresponding author: Nunes Salgado HR, School of Pharmacy, Faculty of Pharmaceutical Sciences, São Paulo State University, Araraquara, São Paulo Brazil, Tel/Fax: +55 16 33016960; E-mail: salgadoh@fcfar.unesp.br

Received December 07, 2012; Accepted January 27, 2013; Published January 31, 2013

Citation: Chierentin L, Nunes Salgado HR (2013) Development and Validation of a Simple, Rapid and Stability-Indicating High Performance Liquid Chromatography Method for Quantification of Norfloxacin in a Pharmaceutical Product. J Chromat Separation Techniq 4: 171. doi:10.4172/2157-7064.1000171

Copyright: (c) 2013 Chierentin L, et al. This is an open-access article distributed under the terms of the Creative Commons Attribution License, which permits unrestricted use, distribution, and reproduction in any medium, provided the original author and source are credited. 
Citation: Chierentin L, Nunes Salgado HR (2013) Development and Validation of a Simple, Rapid and Stability-Indicating High Performance Liquid Chromatography Method for Quantification of Norfloxacin in a Pharmaceutical Product. J Chromat Separation Techniq 4: 171. doi:10.4172/2157-7064.1000171

Page 2 of 5

norfloxacin tablet with a label claim of $400 \mathrm{mg}$ drug was obtained from União Química (Pouso Alegre, Brazil). Eluents and standard solutions were prepared with high-quality water obtained from a Milli-Q system (Millipore, Milford, MA, USA). All chemicals were of an analytical grade and used as received.

\section{HPLC apparatus and conditions}

A Waters HPLC system, consisting in two module pumps, model 1525, a manual injector (Breeze 7725i, Rheodyne) and UV-Vis detector (Waters 2487) at $277 \mathrm{~nm}$, was used. The analyses were carried out on an Eclipse Plus Zorbax $\mathrm{C}_{18}$ Agilent $(150 \mathrm{~mm} \times 4.6 \mathrm{~mm}$ i.d., $5 \mu \mathrm{m}$ particle size) column as a stationary phase. The mobile phase was a mixture of $5 \%$ acetic acid aqueous solution and methanol $(80: 20, \mathrm{v} / \mathrm{v})$ used in mode isocratic elution. Twenty microliters of sample was injected into the HPLC system. The overall run time was $7.0 \mathrm{~min}$ and the flow rate was $1.0 \mathrm{ml} / \mathrm{min}$. All the analyses were carried out at room temperature. Results were acquired and processed by internal software (Empower, Waters, Milford, MA, USA).

\section{Preparation of solutions}

Standard preparation: The norfloxacin standard $(12.5 \mathrm{mg})$ was accurately weighted and transferred into a $25 \mathrm{ml}$ amber volumetric flask and diluted with a solvent mixture of $5 \%$ acetic acid aqueous solution and methanol $(80: 20, \mathrm{v} / \mathrm{v})$ (mobile phase) by $30 \mathrm{~min}$ sonication. This standard solution had a concentration of $500 \mu \mathrm{g} / \mathrm{ml}$. Aliquots of the solution prepared above were transferred to $10 \mathrm{ml}$ amber volumetric flasks to generate solutions to the final concentration required and were then supplemented with purified water. Solutions were filtered through a $0.45 \mu \mathrm{m}$ membrane filter (Sartorius, Texas, USA) prior to injection.

Sample preparation: For the analysis of norfloxacin tablets, twenty tablets were weighed and crushed to a fine powder to obtain a homogeneous mixture. An aliquot of powder equivalent to the weight of $21.91 \mathrm{mg}$, was accurately weighed into a $25 \mathrm{ml}$ amber volumetric flask. The volume was completed with a solvent mixture of $5 \%$ acetic acid aqueous solution and methanol (80:20, v/v) (mobile phase). The resulting solution was sonicated during $30 \mathrm{~min}$ to enable complete dissolution of norfloxacin and filtered using Whatman filter paper $\mathrm{n}^{\circ} 1$. This sample solution had a concentration of $500 \mu \mathrm{g} / \mathrm{ml}$. Aliquots of this solution were accordingly diluted with purified water in $10 \mathrm{ml}$ amber volumetric flask in order to obtain solutions with final concentration required. These solutions were filtered through a $0.45 \mu \mathrm{m}$ nylon filter before injections.

Forced degradation solutions: The stability of norfloxacin was determined by subjecting it to oxidative, alkaline, acidic, neutral, and photolytic conditions in order to accelerate conditions conducive to degradation. The stress solutions were prepared from a solution of 0.5 $\mathrm{mg} / \mathrm{ml}$ and subjected to heating $\left(80^{\circ} \mathrm{C}\right)$. Solutions at a concentration of $22 \mu \mathrm{g} / \mathrm{ml}$ were prepared using purified water and filtered before injection [23].

Oxidation: $3 \% \mathrm{H}_{2} \mathrm{O}_{2}$ solution were prepared at a concentration of $0.5 \mathrm{mg} / \mathrm{ml}$ norfloxacin and placed in water bath at $80^{\circ} \mathrm{C}$ for 96 hours.

Acid, alkali and neutral: Norfloxacin was treated separately with $0.1 \mathrm{M}$ sodium hydroxide and $0.1 \mathrm{M}$ hydrochloric acid at a concentration $0.5 \mathrm{mg} / \mathrm{ml}$. These solutions were exposed to a temperature of $80^{\circ} \mathrm{C}$ in the water bath during $96 \mathrm{hrs}$. Norfloxacin was also treated with purified water at a concentration of $0.5 \mathrm{mg} / \mathrm{ml}$ and was heated at $80^{\circ} \mathrm{C}$ at the same time.

Photostability: The standard solution of norfloxacin was exposed to ultraviolet light (at least 200 watt hours $/ \mathrm{m}^{2}$ ) to determine the effects of radiation. A solution of norfloxacin at a concentration of $0.5 \mathrm{mg} / \mathrm{ml}$, solubilizing the solution with mobile phase and completing the volume with purified water. It was exposed to UV light during 96 hours.

\section{Analytical method validation}

The developed chromatographic method was validated for the following parameters: precision, sensitivity (LOQ and LOD), linearity, accuracy, robustness and system suitability [24].

Precision: The precision of the related substance method was checked by injecting six individual preparations at a concentration of $22 \mu \mathrm{g} / \mathrm{ml}$, against qualified reference standard. The \%RSD area of each sample was calculated. Precision study was also determined by performing $\mathrm{n}=3$ on a different three days (inter-day precision).

Limit of quantification (LOQ) and Limit of detection (LOD): The LOQ and LOD for norfloxacin were calculated from the standard deviation (SD) of response and slope of the curve (S) using the equations: $\mathrm{LOD}=3.3(\mathrm{SD} / \mathrm{S})$ and $\mathrm{LOQ}=10(\mathrm{SD} / \mathrm{S})$, according $\mathrm{ICH}$.

Linearity: For evaluation of the calibration graph, a weighted linear regression was performed with nominal concentrations of calibration standards against measured peak areas. Calibration graph (concentration vs. peak area) was constructed at six concentrations levels $(10,14,18,22,26$ and $30 \mu \mathrm{g} / \mathrm{ml})$. The analytical curve was evaluated on three different days. The slope and y-intercept of the calibration curve was reported.

Accuracy: The accuracy of the method was checked for three different concentration levels $(80 \%, 100 \%$ and $120 \%)$ by standard addition technique. At each concentration, three sets were prepared and injected thrice. The percentage of recovery was calculated at each level.

Robustness: In order to evaluate the robustness of the method the influence of small deliberate variation of analytical parameters on the retention times of norfloxacin was studied. The parameters selected were percentage of methanol in the mobile phase $(18 \%$ and $22 \%)$, wavelength (275 and $279 \mathrm{~nm})$, flow rate $(0.8$ and $1.2 \mathrm{ml} / \mathrm{min})$ and column specifications. Only one parameter was changed while the others were kept constant.

\section{Results and Discussion \\ HPLC method development and validation}

The HPLC method carried out in this work aimed at developing a new system capable of eluting resolving norfloxacin and its degradations products, based on trial and error method, the mobile phase, which gives best possible separation and resolution, was selected and retention time was also taken in to the consideration.

During the development of this method, different compositions of mobile phase were tested. Finally the system containing 5\% acetic acid aqueous solution and methanol $(80: 20, \mathrm{v} / \mathrm{v})$ was found to be satisfactory and gave resolved peaks of norfloxacin (standard and tablets) and degradations products at $277 \mathrm{~nm}$. The retention time for norfloxacin standard was 5.7 minutes (Figure 2).

\section{System suitability}

This test was performed by collection of data from a standard solution containing $22 \mu \mathrm{g} / \mathrm{ml}$ of norfloxacin that was injected six times of standard resolution solution [25]. The parameters measured were tailing factor, capacity factor, theoretical plates, retention time and peak 
Citation: Chierentin L, Nunes Salgado HR (2013) Development and Validation of a Simple, Rapid and Stability-Indicating High Performance Liquid Chromatography Method for Quantification of Norfloxacin in a Pharmaceutical Product. J Chromat Separation Techniq 4: 171. doi:10.4172/2157-7064.1000171

Page 3 of 5

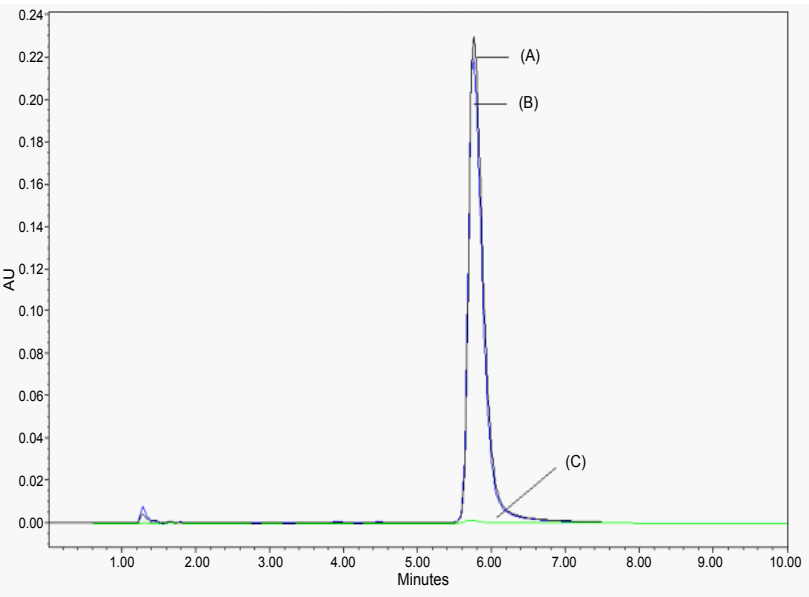

Figure 2: Typical chromatogram of norfloxacin standard (A), norfloxacin dosage form (B) and placebo solution (C)

\begin{tabular}{|l|c|c|c|c|}
\hline & $\begin{array}{c}\text { Amount of standard } \\
\text { norfloxacin added }(\boldsymbol{\mu g} / \mathbf{m l})\end{array}$ & $\begin{array}{c}\text { Total found } \\
(\boldsymbol{\mu} \mathbf{g} / \mathbf{m l})\end{array}$ & $\begin{array}{c}\text { Recovery } \\
(\mathbf{\%})^{*}\end{array}$ & $\begin{array}{c}\text { Mean Recovery } \\
(\%)\end{array}$ \\
\hline R1 & 7.6 & 7.62 & 101.75 & 103.96 \\
\hline R2 & 12.0 & 12.53 & 104.29 & \\
\hline R3 & 16.4 & 17.58 & 105.85 & \\
\hline
\end{tabular}

Table 1: Results of recovery study by standard-addition method.

area. The tailing factor showed less than 2 , the capacity factor was more than 2 and the theoretical plates were more than 2000. The average of retention time was 5.5 minutes and the \%RSD of peak area was $0.93 \%$. The values for system suitability parameters showed feasibility of this method for routine pharmaceutical application. All results are shown in the table 1 .

\section{Precision}

The precision of the proposed method was determined by performing standard solution assay on same day (intra-day) and on three different days (inter-day). Percent of RSD for intra-day and interday assay precision was $0.11 \%$ and $0.79 \%$, respectively.

\section{LOQ and LOD}

The LOQ was calculated by $\mathrm{LOQ}=10(\mathrm{RS} / \mathrm{S})$ and LOD was determined by $\mathrm{LOD}=3.3(\mathrm{RS} / \mathrm{S})$, where $\mathrm{SD}$ is the standard deviation of the response of the blank and $S$ is the slope of calibration curve. The LOQ and LOD values for norfloxacin were found to be $0.32 \mu \mathrm{g} / \mathrm{ml}$ and $0.10 \mu \mathrm{g} / \mathrm{ml}$, respectively. The results indicate to us that this method is much more sensitive than most of the reported methods $[18,17,22]$.

\section{Linearity}

The linearity for detector response was observed in the concentration range of $10-30.0 \mu \mathrm{g} / \mathrm{ml}$ for norfloxacin. The calibration curve was constructed with concentration against peak area. The regression equation for the calibration curve was found to be $y=15145 x-24993$ and the correlation coefficient $\left(\mathrm{r}^{2}\right)$ of 0,999 was obtained. Good linearity was found between the peak area and analyte concentration.

\section{Accuracy}

To make certain the accuracy of the proposed method, recovery studies were carried out by standard addition method at three different levels $(80 \%, 100 \%$ and $120 \%)$ described in table 2. Percent RSD for

\begin{tabular}{|l|c|c|c|c|c|}
\hline $\begin{array}{l}\text { Injection } \\
\text { Number }\end{array}$ & $\begin{array}{c}\text { Retention } \\
\text { Time (min) }\end{array}$ & $\begin{array}{c}\text { Peak area of } \\
\text { norfloxacin }\end{array}$ & $\begin{array}{c}\text { Tailing } \\
\text { factor }\end{array}$ & $\begin{array}{c}\text { Theoretical } \\
\text { plates }\end{array}$ & $\begin{array}{c}\text { Capacity } \\
\text { factor }\end{array}$ \\
\hline 1 & 5.58 & 2995654 & 0.75 & 2200.19 & 3.29 \\
\hline 2 & 5.61 & 2997951 & 0.75 & 2223.92 & 3.31 \\
\hline 3 & 5.61 & 3020060 & 0.72 & 2223.92 & 3.31 \\
\hline 4 & 5.61 & 2994350 & 0.74 & 2223.92 & 3.29 \\
\hline 5 & 5.58 & 3048035 & 0.72 & 2200.19 & 3.29 \\
\hline 6 & 5.59 & 3058041 & 0.74 & 2208.09 & 3.30 \\
\hline Mean & 5.59 & 3019015 & 0.73 & 2213.37 & 3.29 \\
\hline$\% R S D$ & 0.26 & 0.93 & 1.85 & 0.59 & 0.29 \\
\hline
\end{tabular}

Table 2: Data of system suitability of developed method to norfloxacin.

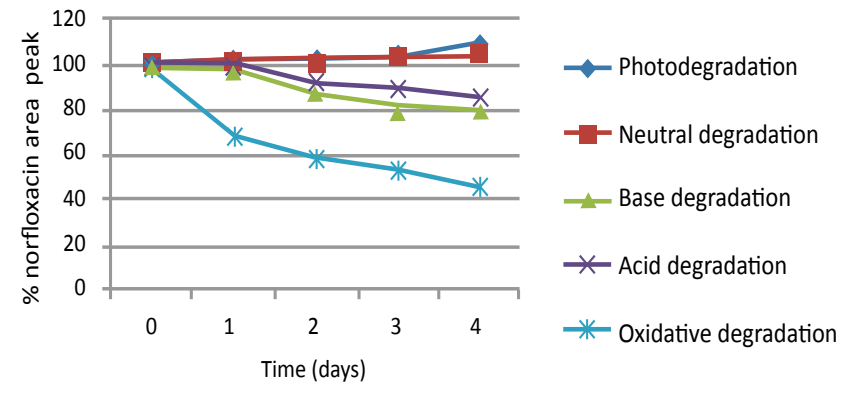

Figure 3: Plot showing the changes $\%$ norfloxacin area peak vs. time. Mean values.

norfloxacin was found to be $1.98 \%$ with a corresponding percentage recovery value of $103.93 \%$.

\section{Robustness}

The robustness of the analytical method was determined by the consistency of the peak height and peak shape with the deliberately small changes in the experimental conditions. It is a measure of its capacity to retain unaffected by small, but deliberate variations in method conditions and provides an indication of its reliability during normal usage [24]. To determine the robustness of the proposed method, the following variations were made in the analytical method: percentage of methanol in the mobile phase (18\% and 22\%), wavelength (275 and 279 $\mathrm{nm})$, flow rate $(0.8$ and $1.2 \mathrm{ml} / \mathrm{min})$ and column was altered to a Luna $\mathrm{C}_{18}$ Phenomenex $(150 \times 4.6 \mathrm{~mm}, 5 \mu \mathrm{m})$. The robustness of the method shows $\%$ RSD value $0.67 \%$, that there were no marked changes in the chromatographic conditions, which demonstrates that the method developed is robust.

\section{Selectivity/specificity}

Through the forced degradation study, was evaluate the specificity of the method indicate the stability [23]. A stability indicating method accurately measures the active ingredients, without interference from degradation products, process impurities, excipients, or other potential impurities.

The specificity of the development method was determined by injecting sample solutions $(22 \mu \mathrm{g} / \mathrm{ml})$ which were prepared by stress conditions, like UV light, neutral, base, acid, and oxidative agent. In two stress conditions (UV light and neutral) peak of norfloxacin increase by $103.37 \%$ and $109.09 \%$, respectively. On the other hand, the norfloxacin peaks in the basic, the acid, and oxidative, stress solutions show a decrease by $78.97 \%, 84.71 \%$ and $46.12 \%$, respectively (Figure 3 ).

Taking into account that three additional peaks (Figures 4-8) appeared in the chromatograms corresponding to the degradation 
Citation: Chierentin L, Nunes Salgado HR (2013) Development and Validation of a Simple, Rapid and Stability-Indicating High Performance Liquid Chromatography Method for Quantification of Norfloxacin in a Pharmaceutical Product. J Chromat Separation Techniq 4: 171. doi:10.4172/2157-7064.1000171

Page 4 of 5

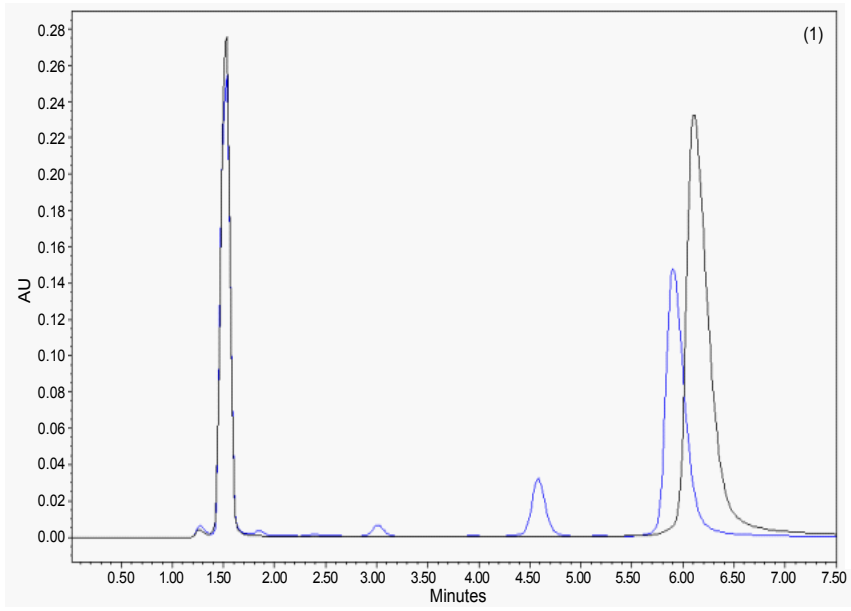

Figure 4: Typical overlapping chromatograms of norfloxacin and oxidative degraded.

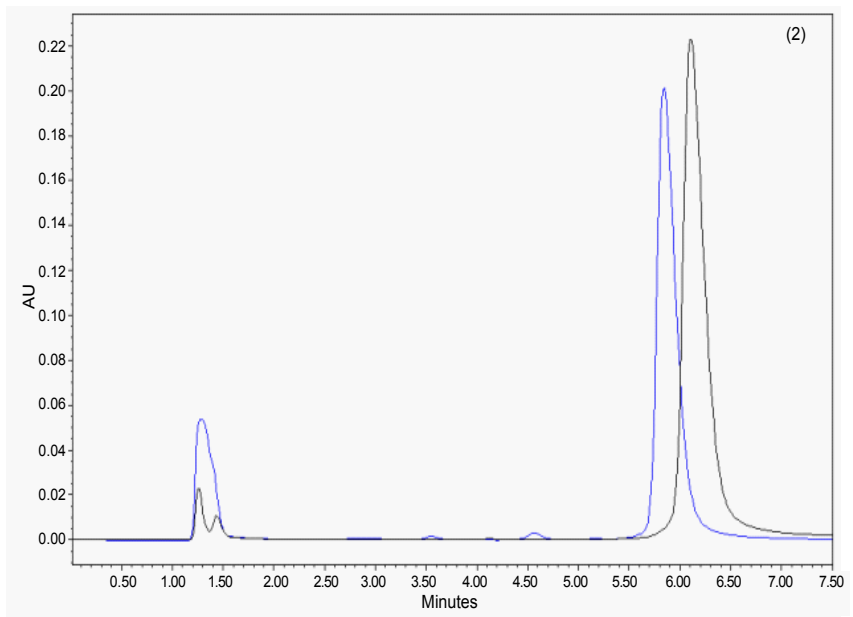

Figure 5: Typical overlapping chromatograms of norfloxacin and base degraded.

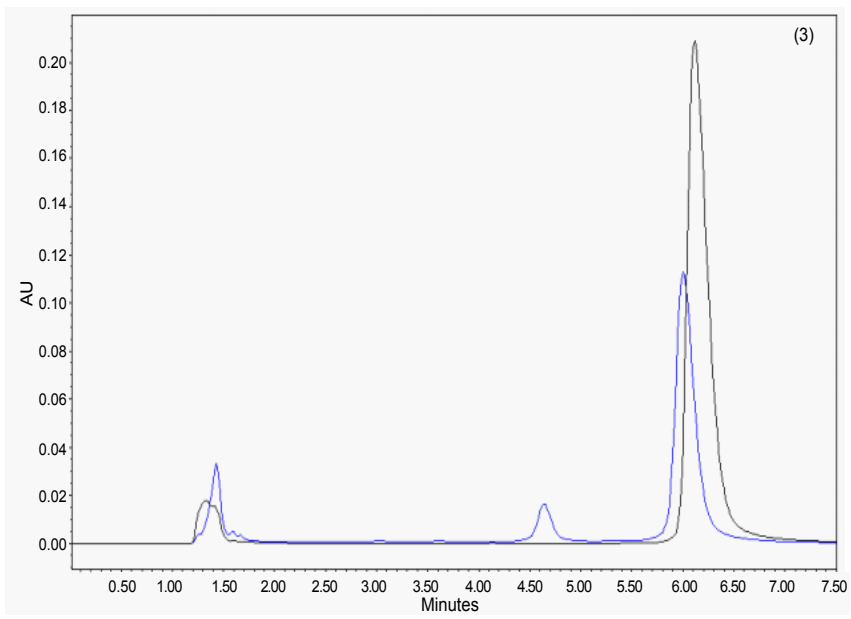

Figure 6: Typical overlapping chromatograms of norfloxacin and acid degraded.

product, with a good selectivity and resolution the compounds, these results seem to suggest that HPLC is a selective and specific method for the analysis of norfloxacin samples from stability studies.

\section{Assay of norfloxacin}

The developed method applied for the determination of norfloxacin content in market formulation (tablets $400 \mathrm{mg}$ ). The result of the assay yielded $102.84 \%(\% \mathrm{RSD}=0.11 \%)$. The assay result showed that this method was sensitive and specific for the quantitative analysis of norfloxacin in dosage form. No significant interference was observed from excipients commonly used in the formulation.

\section{Conclusions}

The proposed stability indication HPLC method is found to be simple, sensitive, accurate, precise, linear, robust and specific for quantitative estimation of norfloxacin dosage forms. The developed chromatographic method was validated using ICH guidelines. The analytical conditions and the solvent developed provided good resolution within a short analysis time and proved to be economical. The proposed method does not need sophisticated and expensive instrumentation.

\section{Acknowledgements}

Deep appreciation for the PACD-FCFAr-UNESP (Araraquara-Brazil), FAPESP process n 2010/13335-2 (São Paulo-Brazil), CNPQ (Brasília-Brazil) and União Química (Minas Gerais-Brazil). We also thank Lindsey Silva by your collaboration.

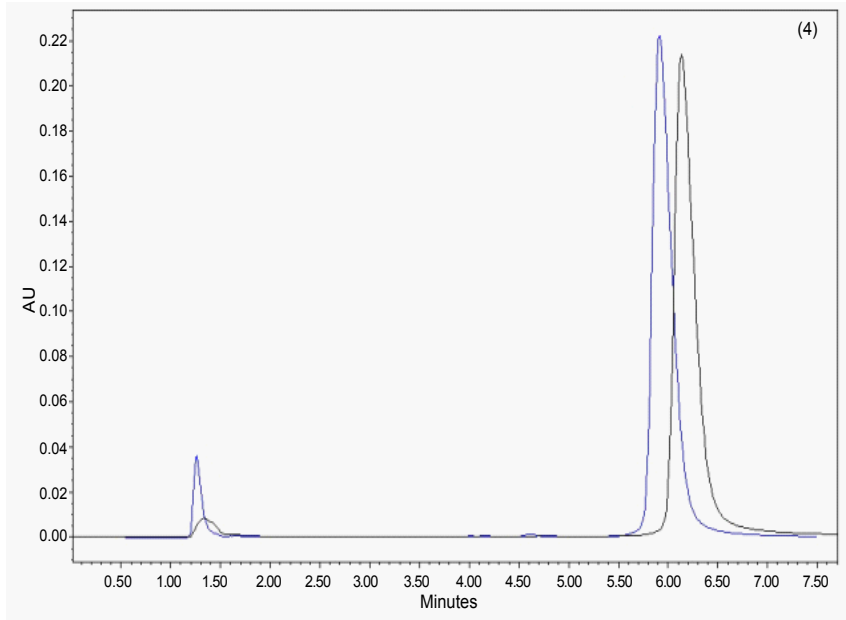

Figure 7: Typical overlapping chromatograms of norfloxacin and neutral degraded.

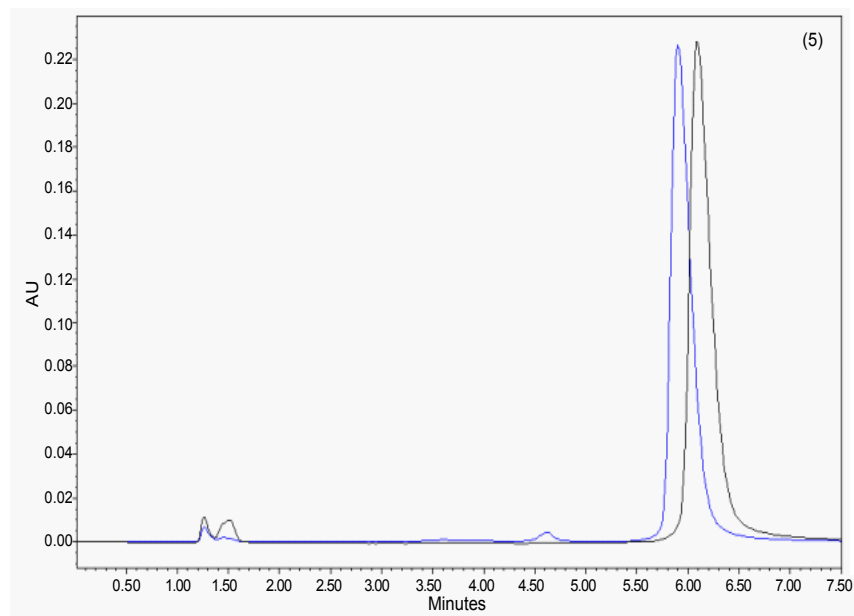

Figure 8: Typical overlapping chromatograms of norfloxacin and photodegraded. 
Citation: Chierentin L, Nunes Salgado HR (2013) Development and Validation of a Simple, Rapid and Stability-Indicating High Performance Liquid Chromatography Method for Quantification of Norfloxacin in a Pharmaceutical Product. J Chromat Separation Techniq 4: 171. doi:10.4172/2157-7064.1000171

Page 5 of 5

\section{References}

1. Pavithra BH, Prakash N, Jayakumar K (2009) Modification of pharmacokinetics of norfloxacin following oral administration of curcumin in rabbits. J Vet Sci 10: 293-297.

2. Boyd LB, Maynard MJ, Morgan-Linnell SK, Horton LB, Sucgang R, et al. (2009) Relationships among ciprofloxacin, gatifloxacin, levofloxacin, and norfloxacin MICs for fluroroquinolone-resistant Escherichia coli clinical isolates. Antimicrob Agents Chemother 53: 229-234.

3. Qadri SM, Johnson S (1989) Antibacterial activity of norfloxacin against bacterial isolates from the urinary tract. J Natl Med Assoc 81: 382-385.

4. Nicolle LE, Harding GK, Thompson M, Kennedy J, Urias B, et al. (1989) Prospective, randomized, placebo-controlled trial of norfloxacin for the prophylaxis of recurrent urinary tract infection in women. Antimicrob Agents Chemother 33: 1032-1035.

5. Hsu YH, Chung MW, Li TK (2006) Distribution of gyrase and topoisomerase IV on bacterial nucleoid: implications for nucleoid organization. Nucleic Acids Res 34: 3128-3138.

6. Morgan-Linnell SK, Boyd LB, Steffen D, Zechiedrich L (2009) Mechanisms accounting for fluoroquinolones resistance in Escherichia coli clinical isolates. Antimicrob Agents Chemother 53: 235-241.

7. Leeming JP, Diamond JP, Trigg R, White L, Hoh HB, et al. (1994) Ocular penetration of topical ciprofloxacin and norfloxacin drops and their effect upon eyelid flora. Br J Ophthalmol 78: 546-548.

8. Brazilian Pharmacopoeia (2001) IV São Paulo, Atheneu.

9. Portuguese Pharmacopoeia (2005) VIII. Lisbon, Tipografia Peres

10. British Pharmacopoeia (2010) VII, Her Majesty's Stationert Office, London, UK

11. The United States Pharmacopoeia (2012) 35, Rockville, USA.

12. Froehlich PE, Schapoval EES (1990) Physical-Chemistry assay method of norfloxacin: ultraviolet spectrophotometric assay method. Ver Ciên Farm 12: 167-170.

13. More VR, Mote US, Patil SR, Kolekar GB (2009) Spectroscopic studies on the interaction between norfloxacin and p-amino benzoic acid: analytical application on determination of norfloxacin. Spectrochim Acta A Mol Biomol Spectrosc 74: 771-775.

14. European Pharmacopoeia (2001), (7thedn) Millefolli Herba, France.

15. Forchetti C, Flammini D, Carlucci G, Cavicchio G, Vaggi L, et al. (1984) High-performance liquid chromatographic procedure for the quantitation of norfloxacin in urine, serum and tissues. J Chromatogr 13: 177-182.

16. Chen C, Liu X, Wu R (1993) High-performance liquid chromatographic method for determination of norfloxacin glutamate and glucoronate in solid and liquid dosage forms and its application to stability testing. J Pharm Biomed Anal 11 : 717-721.

17. Córdoba-Borrego M, Córdoba-Díaz M, Córdoba-Díaz D (1999) Validation of a high-performance liquid chromatographic method for the determination of norfloxacin and its application to stability studies (photo-stability study of norfloxacin). J Pharm Biomed Anal 18: 919-926.

18. Kassab NM, Singh AK, Kedor-Hackmam ERM, Santoro MIRM (2005) Quantitative determination of ciprofloxacin and norfloxacin in pharmaceutica preparations by high performance liquid chromatography. Braz J Pharm Sci 41 : 507-513.

19. Pecorelli I, Galarini R, Bibi R, Floridi Al, Casciarri E, et al. (2003) Simultaneous determination of 13 quinolones from feeds using accelerated solvent extraction and liquid chromatography. Anal Chim Acta 483: 81-89.
20. Espinosa-Mansilla A, Peña AM, Gómez DG, Salinas F (2005) HPLC determination of enoxacin, ciprofloxacin, norfloxacin and ofloxacin with photoinduced fluorimetric (PIF) detection and multiemission scanning application to urine and serum. J Chromatogr B Anlyt Technol Biomed Life Sci 822: 185-193.

21. Patel P, Patel K, Bhatt KK, Patel S (2011) New improved RP-HPLC method for determination of norfloxacin and ornidazole in their combined dosage form. In J Res Pharm Biomed Sci 2: 710-713.

22. Negeswara-Rao R, Nagaraju V (2004) Separation and determination of synthetic impurities of norfloxacin by reversed-phase high performance liquid chromatography. J Pharm Biomed Anal 45: 1049-1056.

23. ICH Stability testing of new drug substances and products Q1A (R2) (2003) International Conference Harmonization, IFPMA, Geneva, Switzerland.

24. ICH Q2 (R1) (2005) Validation of analytical procedures: text and methodology. International Conference, Geneva, Switzerland.

25. Gauhar S, Ali SA, Shoaib H, Naqvi SBS, Muhammad IN (2009) Developmen and validation of HPLC method for determination of pefloxacin in tablet and human plasma. Iran J Basic Med Sci 12: 33-42.
Submit your next manuscript and get advantages of OMICS Group submissions

Unique features:

tation of your paper to 50 world's leading languages

rion of published paper

Digital articles to share and explore

Special features:

250 Open Access Journals

20,000 editorial tean

21 days rapid review process

Quality and quick editorial, review and publication processing

Indexing at PubMed (partial), Scopus, DOAJ, EBSCO, Index Copernicus and Google Scholar etc

Sharing Option: Social Networking Enabled

Authors, Reviewers and Editors rewarded with online Scientific Credits

Better discount for your subsequent articles

Submit your manuscript at: http://www.editorialmanager.com/biochem 